Ayurlog: National Journal of Research in Ayurved Science

\title{
Therapeutic effect of Raktamokshan in the management of gridhrasi with modified version of Shrunga (cupping)
}

\author{
Jadhav Pradnya ${ }^{1}$, Paradkar Hemant ${ }^{2}$, Pathrikar Anaya ${ }^{3}$
}

1. P.G.Scholar,

2. Associate Professor,

3. H.O.D. \& Professor

Department of Kayachikitsa, APM'S Ayurved Mahavidyalaya Sion, Mumbai-400022.

*Corresponding author: Email-Id: pradnyajadhav47@gmail.com

\begin{abstract}
:
The incidence rate of Gridhrasi (sciatica) is quite significant as more than threequarters of the world's population is affected by the disease. It is characterized by the onset of Ruja (pain), Todq. (pricking), and Stambha (stiffness: initially in Sphika (gluteal region) and then radiating distally to Kati-Prishtha (low back), Janu (knee), Jangha (thigh) till Pada (feet). The patients suffering from Gridhrasi have restricted movements due

days for three times and the scores were noted down before and after treatment. The scores were analyzed using the Student's $t$-test. Result: Marked reduction in severity of mean scores of Ruja, Toda, Stambha was seen in the patients after the use of the modified version of srunga (cupping instrument) for Raktamokshana, which was statistically significant. Conclusions: cupping is the simple and effective treatment (in adjunct to other treatment) for reducing Ruka, Toda, Stambha in Gridhrasi.
\end{abstract} to painful limb, affecting the daily routine activities. Aim: To study and evaluate the therapeutic effect of Raktamokshan in the management of Gridhrasi with the modified version of Shrunga. (cupping). Materials and Methods: The study was conducted on twenty patients who had reported for the treatment of Gridhrasi at an Ayurvedic hospital. Raktamokshana was done on Sphik (gluteal region) or Kati (low back) region with the help of 22 no.surgical blades and modified version of shrunga (cupping instrument)in four settings $\left(0,5^{\text {th }}, 10^{\text {th }}\right.$ and $15^{\text {th }}$ day). The sign and symptoms, namely Ruka, Toda, Stambha were given scores depending on their severity. The patients were also assessed for straight-leg raise (SLR) test. Follow-up was done at an interval of 5

Key words: Gridhrasi, shrunga, cupping, sciatica

\section{INTRODUCTION:}

Our Acharya has explained 5 types of shodhan (purificatory procedure) i.e. 1)Vaman2)Virechan 3)Basti 4)Nasya 5)Raktamokshan. Raktamokshan is one of the shodhan procedure which is indicated in many disease where Raktadhatudushti takes place. Acharya Shushruta has explained various types of Raktamokshan procedure in ancient period according to dosha. In Shushruta sutrasthan he mention that...

तत्र वातपित्तकफदुष्टशोणीत यथासंख्यं
श्रुड्घजलौकालाबुभि सेचयेत।(सु.सु. १ ३/४)


He also explained guna of Shrunga,Jalouka and Alabu. ShrungaUshna,Madhura,Snighdha according to Guna used for Vatadushti Raktamokshan. Jalouka-Sheetal,Madhura used for Pittadushta Raktamokshan. AlabuKatu,Ruksha,Tikshna used for Kaphdushta Raktamokshan.

Action of Shrunga ... तत्र प्रच्छिते तनुबस्तिपटलावध्देनश्रड्गेण।

शोणितमवसेचयेदाचूषणात

सान्तर्दीपयालाहवा॥ (सु.सु. १ ३/५,६)

But nowdays Shrunga is not easily available the same action of Shrunga we can do it with the help of glass cups method is known as Cupping which are easily available nowadays.

In Ayurveda,

Gridhrasi is described as one of the Vatavyadhi. The incidence rate of this disease is significant as more than three quarters of the world's population. It i characterized with the onset

Ruja(pain),Toda(pricking)

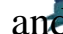

Stambha(stiffness) initially in Sphika (gluteal region)and then radiating distally to Kati-Prushta(lowback),Janu(knee),Jangha (thigh)till Pada(feet).

The line of Management of Gridhrasi according to Ayurveda....

अन्तरा कण्डरागुल्यो शिराबस्त्याग्रिकर्म च। ग्र्रसीषु

प्रयुंजीत. ॥( च.चि. २८/९७)

however in Gridhrsi as Snayu and Rakta are involved Raktamokshan is choice of treatment .

As Vata involvement is evident with or without kapha due to pain and disability.

So,the present study entitled To evaluate the therapeutic effect of Raktamokshan in the management of Gridhrsi with modified version of Shrunga (cupping).

\section{AIM}

To study and evaluate the therapeutic effect of Raktamokshan in the management of Gridhrasi with modified version of Shrunga(cupping).

\section{MATERIALS \& METHODS}

\section{Apparatus used for cupping}

- Glass cups - according to size

- Hand gloves

- Anti septic lotion

- Surgical blade no.22

- Sterile dressing

- Total no. of patient: 20

- Duration of study: 15 days

- Study type: open uncontrolled random study

- Raktmokshan was done on Sphika(gluteal region) or Kati(low back region)with the help of 22 no. surgical blade and appropriate size of cupping glass (modified version of alabu)in four setting $\left(0,5^{\text {th }}, 10^{\text {th }}, 15^{\text {th }}\right)$

- Centre of study: Opd \& Ipd of APM`s ayurved mahavidyalaya \& seth r.v.ayurved hospital sion Mumbai-22

\section{INCLUSIVE CRITERIA}

- Patients of both Genders.

- Age group between 30-70 yrs

- Patient with classical features of Gridhrsi mainly pain over the sphik(gluteal region),kati prushta(back region), uru(thigh region),janu(knee),jangha(calf region)extending up to pada(foot) which is associated with stambha(stiffness),toda(prickin g pain), tingling \& numbness of limbs,difficulty in walking were included in the study.

- Patients with positive straight leg raise (SLR) test. 


\section{EXCLUSIVE CRIETERIA}

- Patients below 30yrs \& adults above 70 yrs.

- Patients with diabetic neuropathy.

- Pregnant women.

- Patients with CA.

\section{PROCEDURE}

\section{PURVA KARMA (Preoperative Procedure):}

Before commencing the procedure SLR test of the patients was done,for this ,patients were asked to lie down in supine position and raise their legs straight and the angle was measured. The patient was advised to lie in the prone position then, the patient was asked to point the highly affected area on sphika or kati-prishta by fingers. Then the site of raktamokshan was selected and disinfected with spirit solution, vaccum created with appropriat size of glass cup.

\section{PRADHAN KARMA Procedure):}

On selected \& disinfected area 4- 5 incisions (superficially) were given with the help of 22 number surgical blade which leads to appropriate sharpness, then the glass cup of appropriate size according to affected area was wiped from inside with spirit gauze which was then quickly placed on the bleeding points \& creates vacuum \& start suction which raises the local area to form bulge and oozing of blood occur. It was kept in the same position till the blood flow stops and blood clots, after which cup is removed and the area was cleaned with sterile gauze piece.

\section{PASCHAT KARMA (Postoperative Procedure):}

Sterile dressings were done over affected area for one day \& patient was asked to take rest. The patient was recalled for follow up for three times at an interval of 5 days. Patients were also observed for any improvement in SLR test after the use of cupping, during the follow up visit.

\section{ASSESSMENT CRITERIA}

Subjective symptoms presented by the patients were given score and were assessed before and after performing of Raktamokshan by cupping. In objective parameter SLR test was done and angle with the help of protractor was noted for comparison.

Gradation for subjective parameter

\section{RUJA (PAIN)}

0: No pain

1: painful walks without limping

2: painful walks with limping but without support

3: painful walk can only with support

4: painful unable to walk

\section{STAMBHA (STIFFNESS)}
0: No stiffness
1: mild stiffness
2: moderate stiffness
3: sever stiffness
4: very sever stiffness

\section{TODA (PRICKING TYPE OF PAIN)}
0: No pricking sensation
1: mild pricking sensation
2: moderate pricking sensation
3: severe pricking sensation
4: very severe pricking sensation 


\section{STATISTICAL ANALYSIS}

Done by applying student paired `t test.

\begin{tabular}{|l|l|l|l|l|l|}
\hline Symptoms & & B.T & A.T & $T$ & P \\
\hline 1)Pain & Mean & 3.4 & 1.55 & 7.59 & $<0.0001$ \\
\hline & $\mathrm{SD}(+/-)$ & 0.680 & 1.190 & & \\
\hline & $\mathrm{SE}(+/-)$ & 0.152 & 0.266 & & \\
\hline 2)Stambha & Mean & 2.9 & 1 & 11.83 & $<0.0001$ \\
\hline & $\mathrm{SD}(+/-)$ & 0.967 & 0.973 & & \\
\hline & $\mathrm{SE}(+/-)$ & 0.216 & 0.217 & & \\
\hline 3)Toda & Mean & 2.95 & 0.9 & 13.35 & $<0.0001$ \\
\hline & $\mathrm{SD}(+/-)$ & 1.099 & 0.967 & & \\
\hline & $\mathrm{SE}(+/-)$ & 0.245 & 0.216 & & \\
\hline 4)SLRT & $\mathrm{Mean}$ & 40.25 & 71.75 & 10.84 & $<0.0001$ \\
\hline & $\mathrm{SD}(+/-)$ & 9.385 & 14.352 & & \\
\hline & $\mathrm{SE}(+/-)$ & 2.098 & 3.209 & & \\
\hline
\end{tabular}

(B.T =Before Treatment, A.T=After Treatment, $\mathrm{SD}=$ Standard deviation, $\mathrm{SE}=$ Standard error, $\mathrm{t}=$ paired " $\mathrm{t}$ " test, $\mathrm{P}=$ Statistically significance)

\section{DISCUSSION:}

Gridhrasi is one of the disease included in vatavikara in all bruhatray included under the 80 types of Nanatmaje Vata Vikara. Sciatica-a condition described in modern medicine resembles with Gridhrasi. In sciatica,there is pain in distribution of sciatic nerve which begins in the lower back and radiates through the posterior aspect of the thigh and calf and to the outer border of foot. Referring to previous study, in Gridhrasi, the main affected area was Sphik, i.e., gluteal region and Kati, i.e., lumbar spine.

Acharya Charaka has described Siravyadha in the management of Gridhrasi. Acharya Sushruta has mentioned that diseases, which are not relieved by Snehana, Lepanadi therapeutic measures can be treated with Siravyadha as an emergency management.

स्नेहादिभि: क्रियायोगैर्न तथा लेपनैरपि।

यान्त्यारु व्याधयः शान्ति यथा सम्यक सिराव्यधात॥(सु.शा.८/२२)

Siravyadha is also accepted as half of the therapeutic measure in Shalya Tantra like Basti in Kayachikitsa. The susceptibility of
Rakta towards impurity is so versatile that the classics were compelled to agree upon Rakta as fourth Dosha. Dushita (vitiated) akta from the related Siras (veins) should be let out to protect the health or to remove the disease. The symptoms and Samyaka Siravedha are Laghavam (body and painful area) and Vedanashanti (pain reduction), bleeding stop itself, it means the pain arising from a disease condition get subsided followed by decrease in the symptoms of the disease so Siravedha can be used in pain predominant diseases.

In previous studies researchers used Siravyadha to let out Rakta Dhatu along with vitiated Doshas and reported that Siravyadha gives spontaneous relief in the cardinal symptoms of Gridhrasi due to release of impurities or Doshas from the affected area. Similarly in the present study vitiated Doshas along with Rakta Dhatu was let out by taking incision with surgical blade on affected area, the vacuum created by the cupping instrument helps the vitiated blood to ooze out. This gives spontaneous relief from symptoms of Gridhrasi due to release of Doshas with the blood from the body. 


\section{CONCLUSION:}

After using cupping instrument as a treatment modality in patients with Gridhrasi, it can be concluded that the use of cupping imparts measurable reduction in the intensity of Ruja, Toda, and Stambha which are the major symptoms of Gridhrasi. Cupping is the simple and effective treatment (in adjunct to other treatment) for Gridhrasi.

\section{REFERANCES:}

1. Dr

Bramhananda

Tripathi,Charaksamhita,2009edition,Chaukhamba Surbharati Publication,Varanasi

2. Sushruta Samhita.Acharya Trikamji,Chaukambha Orientalia, $8^{\text {th }} \quad$ edition 2005, Varanasi

3. Essential orthopaedies:J.Maheshwary( $3^{\text {rd }}$ edition)

4. Braun.J.Inception cohort for orthopathies(pubmed)

5. Lohita BA,Girish KJ.Clinical study to assess the effect of yoga in gridhrasi.IJRAP 2013.

\section{FIGURES:}
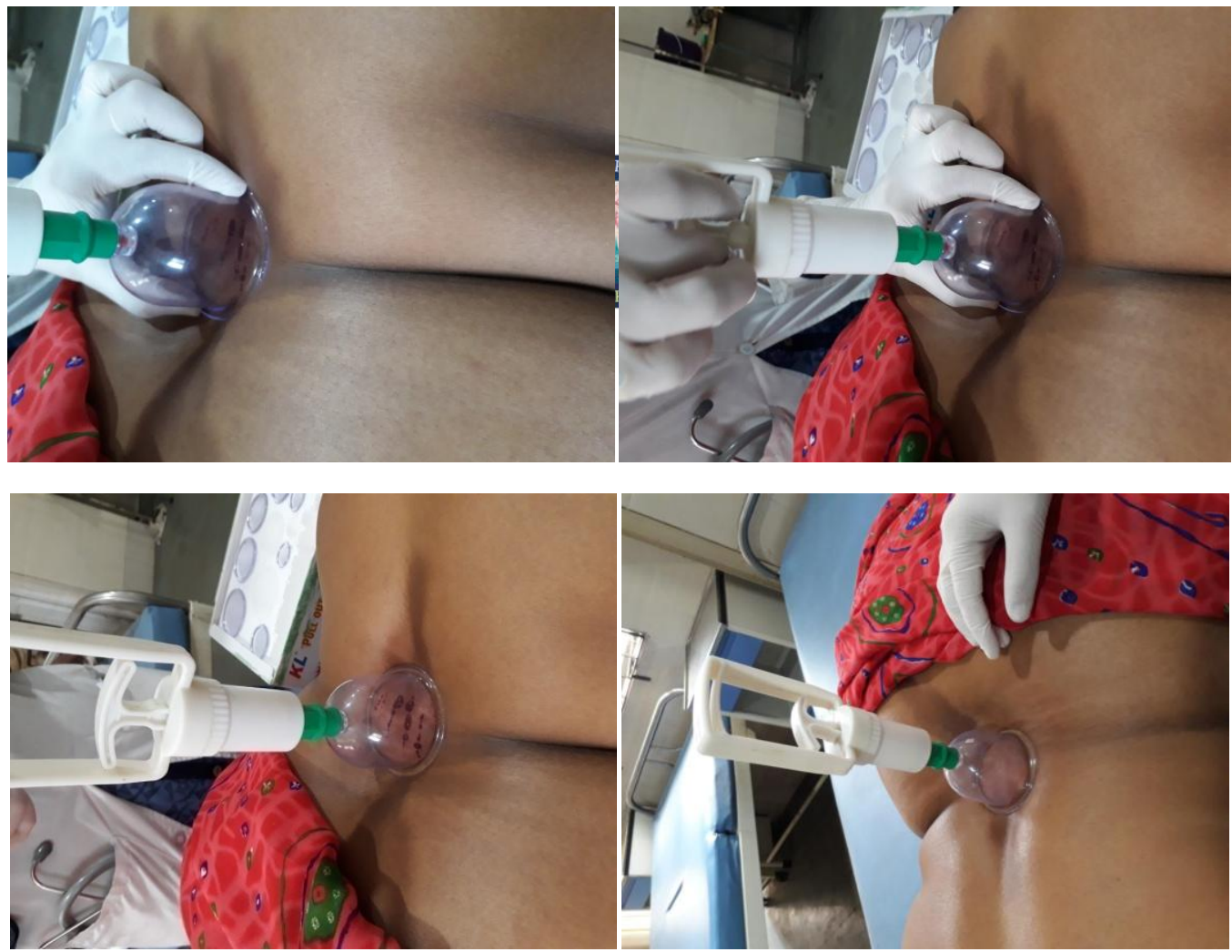

Cite article:

Nvmvbnm , m m,nm,.n

Ayurlog: National Journal of Research in Ayurved Science- 2019; (7)(1): 1-5 